\title{
Editorial
}

\section{La era del desarrollo sostenible}

http://dx.doi.org/10.14718/revfinanzpolitecon.2016.8.2.1

\section{Joan Miguel Tejedor Estupiñán* Juan Fernando Álvarez**}

Las ciencias económicas evolucionan e incluyen nuevas disciplinas de análisis. Mientras el profesor Jeffrey Sachs publicó a fines de 2014 su libro The Age of Sustainable Development, en la Organización de las Naciones Unidas se preparó un ambicioso acuerdo por el desarrollo sostenible, que implica poner medida a las acciones de los países para procurarlo. En 2015 se aprueban los Objetivos de Desarrollo Sostenible y el Vaticano publica la encíclica papal Laudato Si, donde se establecen orientaciones para la preservación de la vida y directrices para un accionar ético. Paralelamente, en París se realiza la XXI Conferencia Ambiental COP21, de la cual se extraen acuerdos para reducir la emisión de gases contaminantes, y ello sin duda implica repensar temas inobjetables como el crecimiento económico que han predominado en las agendas durante las últimas décadas.

Durante 2016, distinguidos profesores de economía norteamericanos postulan al creador de la moneda virtual bitcoin al premio Nobel de economía. A su vez, salen a la luz pública numerosos escándalos relacionados con las nuevas formas de eludir contribuciones fiscales a través de empresas ficticias, muchas de ellas gestionadas a través de computadores remotos desde los cuales se realizan transacciones por fuera de los controles fiscales.

En este contexto se observan crecientes brechas de desigualdad, crisis estructural de los regímenes de bienestar, problemas derivados de conflictos políticos - como el desplazamiento por causa de la guerra, el aumento de refugiados y la ausencia de garantías para su desarrollo humano-, incremento de las tensiones derivadas de la explotación de recursos naturales, incremento de movimientos nacionalistas en desacuerdo con la integración global, exacerbación de los discursos políticos, resistencia a la alternancia de poderes, ampliación de grupos alternativos que realizan iniciativas económicas en contravía de la gran producción transnacional, la cual abarca cada vez más mayor parte de la producción mundial, y una descontrolada producción que deriva en problemas como el calentamiento global y la pérdida de muchos ecosistemas. Lo anterior configura escenarios en los que los postulados económicos deben ampliarse, en busca de generar herramientas que respondan a los crecientes desafíos de una economía y un mundo en continuo cambio.

* Magíster en Derechos Humanos y Economista. Editor de la revista Finanzas y Política Económica, de la Universidad Católica de Colombia. Correo electrónico: jmtejedor@ucatólica.edu.co. Dirección de correspondencia: Facultad de Economía, Universidad Católica de Colombia, Carrera 13 N. 47-49 (Bogotá, Colombia).

** Máster en Economía Social y Economista. Editor-asistente de la revista Finanzas y Política Económica. Correo electrónico: jfalvarez@ucatolica.edu.co. Dirección de correspondencia: Facultad de Economía, Universidad Católica de Colombia, Carrera 13 N. 47-49 (Bogotá, Colombia). 
De manera incipiente, pero creciente, las ciencias económicas incorporan a su instrumental matemático ciertas consideraciones éticas, al tiempo que se amplía su radio de acción en un contexto donde confluyen varias disciplinas cómo la física o la biología, que complejizan los análisis. A ello no es ajena la revista Finanzas y Política Económica, la cual sirve de herramienta de difusión de las investigaciones realizada por autores que, en distintas latitudes, acceden a formar parte de nuestra comunidad científica; una comunidad que necesariamente debe consolidarse a partir de la aplicación del método científico, el estudio riguroso de problemas relevantes y la discusión de los contenidos que se publican.

En este número se divulgan ocho estudios que encajan dentro de las líneas temáticas de la Revista e indagan en distintas brechas del conocimiento. La polivalencia es una característica inherente al avance cognitivo de las ciencias económicas; por ello, desde la revista Finanzas y Política Económica destinamos nuestros esfuerzos a cumplir tales características y esperamos que nuestros lectores puedan hacerse partícipes de estos esfuerzos a partir de sus comentarios, análisis y críticas.

Los primeros tres artículos analizan, con diferentes metodologías e instrumentos, elementos de políticas públicas en el área de las pymes, el efecto de las crisis y las emergencias institucionales en su formulación y la incidencia de la manufactura en el crecimiento económico. El cuarto artículo contribuye, con evidencia empírica, a la causalidad en las variaciones en los niveles de precios y los tipos de interés y de cambio de diferentes países de Latinoamérica. Los siguientes tres artículos enfatizan, desde un análisis empírico, en el ámbito de las relaciones entre la gestión del capital de trabajo y la rentabilidad en un segmento industrial, la medición del impacto de las políticas de formación para el trabajo en Colombia y el efecto que tiene el precio mundial del café en el precio minorista para las cinco ciudades principales del país. El último artículo explora metodológicamente los incentivos que en políticas públicas se establecen para nuevas formas de hacer economías.

En general, estos artículos tratan de forma empírica algunos de los desafíos cognitivos de las ciencias económicas; de allí se derivan nuevas respuestas para entender y superar las crecientes tensiones de un sistema económico en cambio.

\section{REFERENCIAS}

1. Organización de Naciones Unidas (ONU) (2015a). Objetivos de Desarrollo Sostenible. Recuperado de http://www.un.org/sustainabledevelopment/es/objetivos-de-desarrollo-sostenible/

2. Organización de Naciones Unidas (ONU) (2015b). XXI Conferencia Internacional sobre Cambio Climático. Recuperado de http://unfccc.int/resource/docs/2015/cop21/spa/109s.pdf

3. Papa Francisco (2015). Carta Encíclica Laudato Si: Sobre el cuidado de la casa común. Recuperado de http:// w2.vatican.va/content/francesco/es/encyclicals/documents/papa-francesco_20150524_enciclica-laudatosi.html

4. Sachs, J. (2015). La era del desarrollo sostenible. Barcelona: Deusto. 


\section{Editorial}

\section{The age of sustainable development}

http://dx.doi.org/10.14718/revfinanzpolitecon.2016.8.2.1

\section{Joan Miguel Tejedor Estupiñán* Juan Fernando Álvarez**}

The economic sciences have evolved and include new disciplines of analysis. While in 2014, Professor Jeffrey Sachs published his book The Age of Sustainable Development, the United Nations prepared an ambitious agreement for sustainable development, which implies the imposing of measures on country's actions in order to achieve this. In 2015, the Sustainable Development Goals were approved and the Vatican published the Papal encyclical, Laudato Si, which establishes life preserving guidelines and recommendations for ethical conduct. In parallel, Paris played host to the XXI COP21 United Nations Climate Change Conference, in which agreements were reached on reducing the emission of polluting gases, undoubtedly implying a rethinking of uncontestable issues such as economic growth which has dominated the agendas of the past decades.

In 2016, distinguished US economy professors nominated the creator of the virtual currency bitcoin for the Nobel Prize in Economic Sciences. In the same year, a number of scandals came to light. They were related to new modes of tax evasion through the creation of fictitious companies, many of them managed through remote computers from which transactions are carried out away from stringent tax control measures.

This context sheds light on growing gaps in inequality; structural crises of welfare regimes; problems derived from political conflicts such as displacement due to war, increased numbers of refugees, and the absence of guarantees for their human development; increased tensions derived from the exploitation of natural resources; ever-increasing numbers of nationalist movements in disagreement with global integration; the exacerbation of political discourses; resistance to power-sharing; the amplification of alternative groups that implement economic initiatives that go against large-scale transnational production, and which increasingly cover most of the global production; and an uncontrolled production leading to problems such as global warming and the loss of many ecosystems. The above configures the scenarios in which economic proposals need to be amplified in order to generate tools that respond to the growing challenges of an ever-changing economy and world.

Joan Miguel Tejedor Estupiñán has a degree in Economics and an MA in Human Rights, and is the editor of the Finanzas y Economic Policy Review, at Universidad Católica de Colombia. E-mail: jmtejedor@ucatólica.edu. co. Correspondence address: Facultad de Economía, Universidad Católica de Colombia, Carrera 13 N. ${ }^{\circ}$ 47-49 (Bogotá, Colombia)

** Juan Fernando Álvarez has a degree in Economics and an MA in Social Economy, and he is the assistant editor of the Finanzas y Economic Policy Review. E-mail: jfalvarez@ucatolica.edu.co. Correspondence address Facultad de Economía, Universidad Católica de Colombia, Carrera 13 N. 47-49 (Bogotá, Colombia). 
Slowly but surely, the economic sciences are incorporating a number of ethical considerations in their mathematical model, at the same time as amplifying their sphere of action in a context in which disciplines such as physics or biology converge and complicate the analyses. The Finanzas y Economic Policy Review is no stranger to this, and it serves as an instrument for the diffusion of the research undertaken by authors who, in different latitudes, become part of our scientific community. That is, a community which necessarily must consolidate itself through the bases of the application of the scientific method, the rigorous study of relevant problems, and discussion of the contents that are published.

This issue includes eight studies that fit within the thematic lines of the Review and investigate different knowledge gaps. Versatility is a characteristic inherent to cognitive progress in the economic sciences, and in the Finanzas y Economic policy Review, our efforts are aimed at fulfilling such characteristics. We hope that our readers participate in these efforts through their comments, analysis, and critique.

Using different methodologies and instruments, the first three articles analyze aspects of public policy for SMEs, the effects of crises on public policy, and institutional emergencies in their formulation, as well as the incidence of manufacture on economic growth. The fourth article contributes, with empirical evidence, to knowing the price levels, and the types of interest and exchange rates in different Latin American countries. The following three articles emphasize, through empirical analysis, the field of relationships between the management of the working capital and corporate profitability in an industrial sector, the measurement of the impact of training for employment policies in Colombia, and the effect of the global coffee prices on the retail price in the country's five main cities. The last article, methodologically explores the incentives established in public policies for new ways of doing economics.

On the whole, these articles empirically treat some of the cognitive challenges inherent to the economic sciences, coming up with new answers to understand and overcome the growing tensions of a changing economic system.

\section{REFERENCES}

1. The United Nations (UN) (2015a). Sustainable Development Goals. Recovered from http://www.un.org/ sustainabledevelopment/

2. The United Nations (UN) (2015b). XXI Climate Conference. Recovered from http://unfccc.int/resource/ docs/2015/cop21/spa/109s.pdf

3. Pope Francis (2015). Encyclical Letter Laudato si: On Care for Our Common Home. Recovered from http:// w2.vatican.va/content/francesco/en/encyclicals/documents/papa-francesco_20150524_enciclica-laudatosi.html

4. Sachs, J. (2014). The age of sustainable development. New York: Columbia University Press. 


\section{Editorial}

\section{A era do desenvolvimento sustentável}

http://dx.doi.org/10.14718/revfinanzpolitecon.2016.8.2.1

\section{Joan Miguel Tejedor Estupiñán* Juan Fernando Álvarez**}

As ciências econômicas evoluíram e incluíram novas disciplinas de análise. Enquanto o professor Jeffrey Sachs publicou, no final de 2014, seu livro The Age of Sustainable Development, na Organização das Nações Unidas se preparou um ambicioso acordo para o desenvolvimento sustentável que implica estabelecer as medidas para sua conquista.

Em 2015, aprovam-se os Objetivos de Desenvolvimento Sustentável, e o Vaticano publica a encíclica papal Laudato Si, na qual são estabelecidas orientações para a preservação da vida e diretrizes para um agir ético. Paralelamente, em Paris, realiza-se a XXI Conferência do Clima (COP21), da qual se originam acordos para reduzir a emissão de gases poluentes, o que, sem dúvidas, acarreta repensar temas não discutíveis, como o crescimento econômico, que têm predominado nas agendas durante as últimas décadas.

Durante 2016, reconhecidos professores de economia norte-americanos indicam o criador da moeda virtual bitcoin ao prêmio Nobel de economia. Por sua vez, saem à luz pública numerosos escândalos relacionados com as novas formas de desviar contribuições fiscais por meio de empresas fantasmas, muitas delas dirigidas por computadores remotos a partir dos quais se realizam transações ilegais.

Nesse contexto, observam-se crescentes brechas de desigualdades, crise estrutural dos regimes de bem-estar, problemas derivados de conflitos políticos — como o deslocamento humanitário por causa da guerra, o aumento de refugiados e a ausência de garantias para seu desenvolvimento humano-, aumento das tensões derivadas em desacordo com a integração global, exacerbação dos discursos políticos, resistência à alternância de poderes, ampliação de grupos alternativos que realizam iniciativas econômicas na contramão da grande produção transnacional, a qual abrange, cada vez mais, maior parte da produção mundial, e uma descontrolada produção que deriva em problemas como o aquecimento global e a perda de muitos ecossistemas. Tudo isso configura cenários nos quais os princípios econômicos devem ser ampliados em busca de gerar ferramentas que respondam aos crescentes desafios de uma economia e de um mundo em contínua mudança.

De maneira incipiente, mas crescente, as ciências econômicas incorporam a seu instrumental matemático certas considerações éticas, ao mesmo tempo que se amplia seu campo de ação num contexto

* Mestre em direitos humanos e economista. Editor da revista Finanzas y Política Económica, da Universidad Católica de Colombia. E-mail: jmtejedor@ucatólica.edu.co. Endereço postal: Facultad de Economía, Universidad Católica de Colombia, Carrera 13 n. 47-49 (Bogotá, Colombia).

** Mestre em economia social e economista. Editor-assistente da revista Finanzas y Política Económica. E-mail: jfalvarez@ucatolica.edu.co. Endereço postal: Facultad de Economía, Universidad Católica de Colombia, Carrera 13 n. 47-49 (Bogotá, Colombia).. 
em que convergem várias disciplinas como a física e a biologia, que tornam as análises complexas. A revista Finanzas y Política Económica não é alheia a isso, ela serve de ferramenta de difusão das pesquisas realizadas por autores que, em diferentes latitudes, decidem fazer parte de nossa comunidade científica; uma comunidade que necessariamente deve ser consolidada a partir da aplicação do método científico, do estudo rigoroso de problemas relevantes e da discussão dos conteúdos que são publicados.

Neste número, são divulgados oito estudos que estão em consonância com as linhas temáticas da revista e trazem reflexões a diferentes áreas do conhecimento. A polivalência é uma característica inerente ao progresso cognitivo das ciências econômicas; por isso, a revista Finanzas y Política Económica destina seus esforços a cumprir com essas características e espera-se que seus leitores possam se tornar partícipes dessa missão a partir de seus comentários, análises e críticas.

Os primeiros três artigos analisam, com diferentes metodologias e instrumentos, elementos de políticas públicas na área das PMEs, o efeito das crises bem como as emergências institucionais em sua formulação, e a incidência da manufatura no crescimento econômico. O quarto artigo contribui, com evidência empírica, para a causalidade nas variações nos níveis de preços e nos tipos de juros e de câmbio de diferentes países da América Latina. Os seguintes três artigos se enfatizam, sob uma análise empírica, no âmbito das relações entre a gestão do capital de trabalho e a rentabilidade num segmento industrial; a medição do impacto das políticas de formação para o trabalho na Colômbia e o efeito que o preço mundial do café tem no preço varejista para as cinco cidades principais desse país. O último artigo explora metodologicamente os incentivos que em políticas públicas são estabelecidos para novas formas de fazer economias.

Em geral, estes artigos tratam, de forma empírica, sobre alguns dos desafios cognitivos das ciências econômicas; disso se derivam novas respostas para entender e superar as crescentes tensões de um sistema econômico em transformação.

\section{REFERÊNCIAS}

1. Organização das Nações Unidas (ONU) (2015a). Objetivos de Desarrollo Sostenible. Recuperado de http://www.un.org/sustainabledevelopment/es/objetivos-de-desarrollo-sostenible /

2. Organização das Nações Unidas (ONU) (2015b). XXI Conferência Internacional sobre Mudança Climática. Recuperado de http://unfccc.int/resource/docs/2015/cop21/spa/109s.pdf

3. Papa Francisco (2015). Carta Encíclica Laudato Si: sobre o cuidado da casa comum. Recuperado de http:// w2.vatican.va/content/francesco/es/encyclicals/documents/papa-francesco_20150524_enciclica-laudatosi.html

4. Sachs, J. (2014). The age of sustainable development. New York: Columbia University Press. 